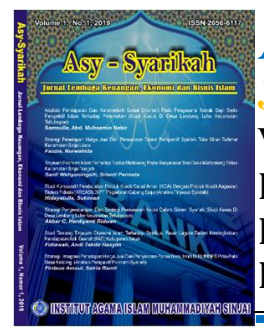

Volume 2, No. 2, 2020

ISSN (print) : 2656-6117

ISSN (online) : 2715-0356

Homepage : http://journal.iaimsinjai.ac.id/index.php/asy-syarikah

\title{
ISLAMIC FINANCIAL DISTRESS
}

\author{
Sahrani ${ }^{1}$ Abd. Muhaemin Nabir ${ }^{2}$ \\ ${ }^{1}$ UIN Syarif Hidayatullah Jakarta \\ ${ }^{2}$ Institut Agama Islam Muhammadiyah Sinjai
}

Korespondensi Penulis, Email: Shabrinatullatifah@gmail.com,eminji511@gmail.com

\begin{abstract}
Abstrak
Penelitan ini bertujuan untuk membuat sebuah integrasi ilmu pengetahuan di bidang Ekonomi Islam dalam membuat model persamaan untuk menghitung nilai-nilai kebangkrutan suatu perusahaan/lembaga. Metode analisis yang digunakan adalah regresi data panel melalui perhitungan altman Z Score. Ketika sebuah perusahaan/lembaga mulai menunjukkan tingkat kesehatan yang buruk, sebagai seorang manager keuangan kebijakan yang dilakukan haruslah didasarkan pada segala pertimbangan agar perusahaan/lembaga tersebut masuk ke dalam zona aman, salah satu metode yang digunakan adalah melalui identifikasi financial distress. Kondisi perusahaan di masa financial distress akan terlebih dahulu mendatangi perusahaan tersebut sebelum mengalami kebangkrutan. Integrasi nilai-nilai Islam terhadap teori-teori yang telah ada merupakan amanah kepada seluruh civitas akademik. Hasil penelitian ini adalah agar perusahaan terhindar dari kondisi financial distress yang mengarah kepada kebangkrutan. Caranya adalah dengan kemampuan memperoleh laba, likuiditas dan tingkat hutang dalam struktur permodalan serta tak kalah pentingnya peningkatan nilai ibadah. return saham mempengaruhi financial distress perusahaan. Penyebab turunnya return saham, yaitu kepekaan perusahaan terhadap tekanan kondisi ekonomi makro ini merupakan penyebab dari financial distress perusahaan.
\end{abstract}

Kata kunci: Islamic financial, keuangan perusahaan

\begin{abstract}
This research aims to create an integration of science in the field of Islamic Economics in making equation models to calculate the bankruptcy values of a company/institution. The analytical method used is panel data regression through the calculation of the altman $Z$ Score. When a company / institution starts to show a poor health level, as a financial manager, the policies that are carried out must be based on all considerations so that the company / institution enters a safe zone, one of the methods used is through financial distress identification. The condition of the company in a period of financial distress will first come to the company before it goes bankrupt. The integration of Islamic values into existing theories is a mandate for the entire academic community. The results of this study are that the company can avoid financial distress that leads to bankruptcy. This is done by the ability to earn profits, liquidity and level of debt in the capital structure and no less important to increase the value of worship. Stock returns affect the company's financial distress. The cause of the decline in stock returns, namely the company's sensitivity to pressure from macroeconomic conditions, is the cause of the company's financial distress.
\end{abstract}

Keywords: Islamic financial, corporate finance 


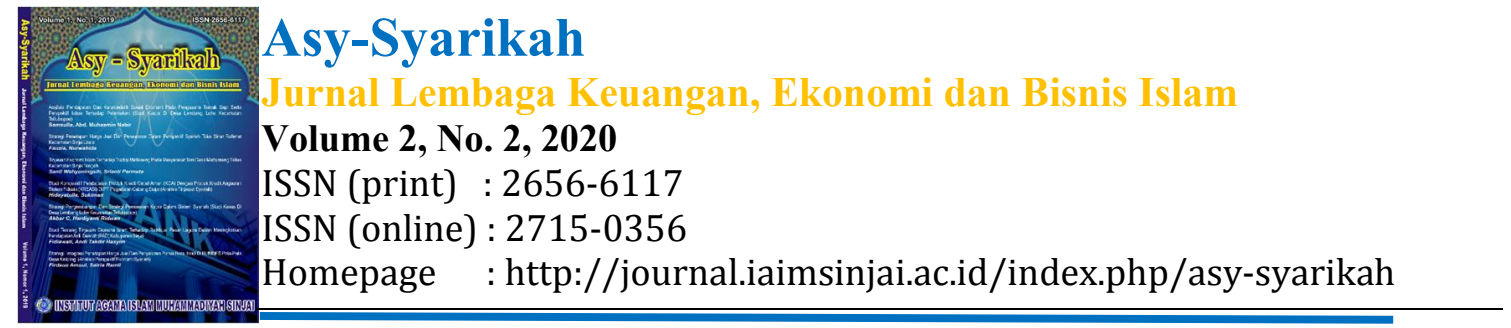

1. Pendahuluan

Kondisi keuangan perusahaan adalah suatu tampilan secara utuh atas keuangan perusahaan selama periode atau kurun waktu tertentu.Media yang dapat dipakai untuk menilai kondisi keuangan perusahaan adalah laporan keuangan yang terdiri atas neraca, perhitungan laba rugi, ikhtisar laba yang ditahan, dan laporan posisi keuangan.Kondisi keuangan perusahaan menggambarkan kesehatan perusahaan sesungguhnya.(Ramadhany, Putro, \& Yovita, 2016)Menurut Mc. Keown (1991) semakin memburuk atau terganggunya kondisi keuangan suatu perusahaan maka semakin besar kemungkinan perusahaan menerima opini audit going concern. Sebaliknya perusahaan yang tidak pernah mengalami kesulitan keuangan, auditor tidak pernah memberikan opini audit going concern.Penelitian mengenai kebangkrutan perusahaan diawali dari analisis rasio keuangan, karena laporan keuangan lazimnya memiliki informasi-informasi penting mengenai kondisi dan prospek perusahaan dimasa yang akan dating.(Fanny \& Saputra, 2005) Beaver telah melakukan studi tentang kerentanan perusahaan terhadap kegagalan, lima tahun sebelum perusahaan dinyatakan mengalami kesulitan keuangan. Studi serupa juga dilakukan untuk menemukan sebuah model prediksi kebangkrutan dalam beberapa periode sebelum kebangkrutan benarbenar terjadi.(Altman, 1968; Fanny \& Saputra, 2005) Altman dan Mc.Gough menemukan bahwa prediksi dengan tingkat kebangkrutan dengan menggunakan suatu modal prediksi mencapai tingkat keakuratan $82 \%$ dan menyarankan penggunaan model prediksi kebangkrutan sebagai alat bantu auditor untuk memutuskan kemampuan perusahaan mempertahankan kelangsungan hidupnya, penggunaan model prediksi kebangkrutan yang dikembangkan oleh Altman mempengaruhi ketetapan pemberian opini audit(Fanny \& Saputra, 2005). Penelitian lain juga berhasil membuktikan bahwa model prediksi kebangkrutan Altman berpengaruh terhadap penerimaan opini audit going concern. Hal ini menunjukan bahwa perusahaan yang terancam bangkrut berpeluang mendapatkan opini audit going concern dari auditor(Setyarno, Januarti, \& Faisal, 2006).

Mutchler (1985) yang dikutip oleh santosa (2007) mengungkapkan beberapa karakteristik dari suatu perusahaan bermasalah, antara lain perusahaan memiliki modal total negatif, arus kas negatif, pendapat operasi negatif, modal kerja negatif, kerugian pada tahun berjalan dan defisit saldo laba tahun berjalan.Carcello dan Neal (2000) dalam Setyarno dkk (2007) menyatakan bahwa semakin buruk kondisi keuangan perusahaan maka semakin besar probabilitas perusahaan menerima opini going concern. Dengan menggunakan model prediksi Altman Z Score Altman, hasil penelitian Ramadhany (2004) selaras dengan penelitian Fanny dan Saputra (2007) menemukan bahwa penggunaan model prediksi kebangkrutan yang dikembangkan oleh Altman mempengaruhi ketepatan pemberian opini audit. Penelitian yang dilakukan Setyarno dkk (2007) juga membuktikan bahwa model prediksi kebangkrutan Altman berpengaruh terhadap penerimaan opini audit going concern. Sampai dengan saat ini, Altman Z Score model ini masih lebih banyak digunakan oleh para peneliti, praktisi, serta para akademis di bidang akuntansi dibandingkan model prediksi kebangkrutan lainnya Altman (dalam Fanny dan Saputra, 2005).

\section{Metode}

Metode yang digunakan adalah melalui identifikasi financial distress. Kondisi perusahaan di masa financial distress akan terlebih dahulu mendatangi perusahaan tersebut sebelum mengalami kebangkrutan. Integrasi nilai-nilai Islam terhadap teori-teori yang telah ada merupakan amanah kepada seluruh civitas akademik.

\section{Pembahasan}




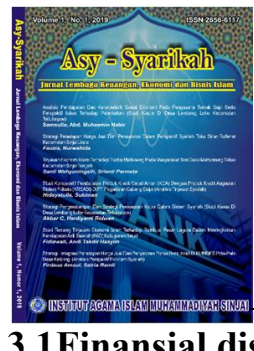

Asy-Syarikah

Jurnal Lembaga Keuangan, Ekonomi dan Bisnis Islam

Volume 2, No. 2, 2020

ISSN (print) : 2656-6117

ISSN (online) : 2715-0356

Homepage : http://journal.iaimsinjai.ac.id/index.php/asy-syarikah

\subsection{Finansial distress}

Financial distress pada dasarnya sukar untuk didefinisikan secara tepat. Hal ini disebabkan oleh bermacam-macam kejadian kejatuhan perusahaan pada saat financial distress. Peristiwa kejatuhan perusahaan yang disebabkan financial distress hampir tidak ada akhirnya, seperti berikut ini : terjadinya pengurangan dividen, penutupan perusahaan, kerugian-kerugian, pemecatan, pengunduran diri direksi dan jatuhnya harga saham.

Financial distress terjadi sebelum kebangkrutan. Tidak ada istilah yang tetap mengenai financial distress dari studi-studi yang ada sebelumnya. Setiap studi mengambil masing-masing definisinya sendiri. Dalam penelitian terdahulu financial distress dapat diartikan sebagai berikut :

1. Jika beberapa tahun perusahaan mengalami laba bersih operasi ( netoperating income) negatif, digunakan oleh Hofer (1980) dan Whitaker (1999).

2. Adanya pemberhentian tenaga kerja atau menghilangkan pembayaran deviden, digunakan oleh Lau (1987) dan Hill, et al. (1996)

3. Arus kas hasil operasi perusahaan tidak cukup untuk memenuhi kewajiban perusahaan, digunakan oleh Karen Wruck (1990)

4. Rendahnya Interest Coverage Ratio, atau EBITDA negatif, digunakan oleh Asquith, et.al. (1991) dan Pindando, et.al. (2006)

5. Perubahan harga ekuitas atau EBIT negatif, digunakan oleh John, et.al (1992) dalam Platt (2004)

6. Stock-based insolvency yaitu kekayaan bersih negatif dan nilai asset kurang dari nilai hutang dan flow -based insolvency yaitu arus kas yang berjalan tidak cukup untuk memenuhi kewajiban, digunakan oleh Altman (1993)

7. Adanya arus kas yang lebih kecil dari hutang jangka panjang saat ini digunakan oleh Whitaker (1999)

8. Perusahaan diberhentikan operasinya atas wewenang pemerintah dan perusahaan tersebut dipersyaratkan untuk melakukan perencanaan restrukturisasi, digunakan oleh Tirapat dan Nittayagasetwat (1999)

9. Negatif EBITDA Interest Coverage, Negatif EBIT, Negatif Net Income digunakan oleh Platt (2004)

10. Beberapa tahun mengalami laba bersih operasi (net operating income) negatif dan selama lebih dari satu tahun tidak melakukan pembayaran deviden, digunakan oleh Almilia dan Kristijadi (2003)

11. Perusahaan mengalami delisted akibat laba bersih dan nilai buku ekuitas negatif berturut-turut, serta perusahaan tersebut telah dimerger, digunakan oleh Almilia (2004)

12. Perusahaan yang selama dua tahun berturut-turut mengalami laba bersih (net income) negatif dan nilai buku ekuitas negatif, digunakan oleh Almilia (2006)

Financial distress menurut Karen Wruck (1990) dalam Ross (2005) adalah situasi dimana arus kas operasi perusahaan tidak cukup, untuk memenuhi kewajiban perusahaan (seperti kredit perdagangan atau biaya bunga ) dan perusahaan ditekan untuk melakukan kegiatan perbaikan. Definisi financial distress ini diperluas oleh Altman (1993) terkait pada ketidakmampuan membayar hutang. Hal ini dirumuskan dalam Black's LawDictionary sebagai : Ketidakmampuan membayar hutang (insolvency), kondisi dari aset atau milik dan kewajiban seseorang yang dahulunya tersedia menjadi tidak cukup untuk melunasi hutang. Definisi ini mempunyai dua bagian yaitu Stock dan Flow. Keduanya menggambarkan mengenai ketidakmampuan membayar hutang (insolvency) stock-based insolvency terjadi ketika perusahaan memiliki kekayaan bersih yang negatif dan nilai aset kurang dari nilai hutang. Flow-based insolvency terjadi ketika arus kas yang berjalan tidak cukup untuk 


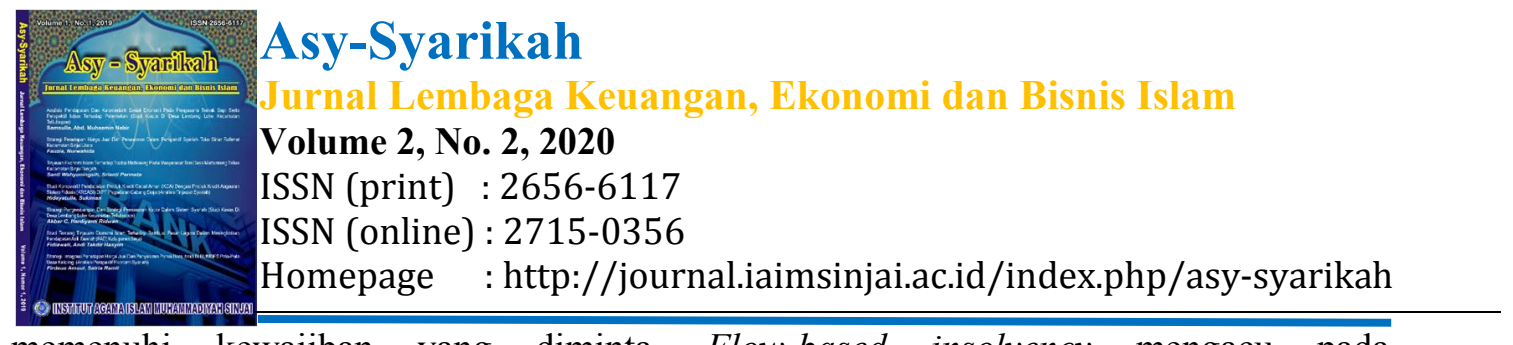

memenuhi kewajiban yang diminta. Flow-based insolvency mengacu pada ketidakmampuan perusahaan untuk membayar hutang.

Asquith, et.al.(1991) mendifinisikan financial distress berdasarkan interest coverage ratio. Perusahaan yang diklasifikasikan mengalami financial distress, jika dua tahun setelah issuing junk bonds, earning before interest, taxes, depreciation and amortization (EBITDA), kurang dari interest expense, atau dalam satu tahun EBITDA kurang dari 80 persen dari interest expense. Mereka tidak memasukan perusahaan dalam kondisi financial distress jika mempunyai interest coverage ratio diantara 0,8 dan 1,0 dalam satu tahun. Hal ini disebabkan karena beberapa perusahaan yang puas pada kondisi ini tidak mengambil langkah perbaikan yang berbeda dalam merespon distress, karena mempunyai dana likuid yang cukup untuk memenuhi pembayaran. Pindando, et.al. (2006) mengadopsi definisi yang sama dengan Asquith, et.al., (1991), financial distress dikondisikan sebagai : EBITDA lebih rendah dari financial expenses, selama dua tahun, dimana perusahaan tidak mampu menghasilkan dana aktivitas operasional untuk memenuhi tanggung jawab keuangannya dan jatuhnya marketvalue selama periode dua tahun tersebut.

Almilia dan Kristijadi (2003) mendefinisikan financial distress pada perusahaan yang dalam beberapa tahun mengalami laba bersih operasi ( net operating income) negatif dan selama lebih dari satu tahun tidak melakukan pembayaran deviden. Kemudian Almilia (2004) mendifinisikan financial distress sebagai perusahaan yang mengalami delisted akibat laba bersih dan nilai buku ekuitas negatif berturut-turut serta perusahaan tersebut telah dimerger. Almilia juga mendefinisikan financial distress sebagai perusahaan yang selama dua tahun berturut-turut mengalami laba bersih ( net income) negatif dan nilai buku ekuitas negatif tahun 2006.

Dalam membuat keputusan, seorang manajer keuangan haruslah mempertimbangkan segala aspek dengan melihat setiap sudut pandang. Financial distress merupakan kondisi dimana sebuah perusahaan harus bangkit dan melakukan penyelamatan aset dan semua yang berhubungan dengan kelangsungan hidup perusahaan tersebut. Kehancuran sebuah perusahaan akan memutus banyak hal, salah satunya adalah tenaga kerja. Ketika sebuah perusahaan berada dalam kondisi seperti ini, tak jarang manager keuangan melakukan pemutusan hubungan kerja secara sepihak. Dalam hal ini tujuan manager tersebut ingin mengurangi beban pengeluaran, namun ada bagian lain yang tak tersentuh dalam proses pengambilan keputusan tersebut. kehilangan pekerjaan seorang kepala rumah tangga adalah sebuah bencana dalam keluarga tersebut. Menyelamatkan seorang kepala rumah tangga akan menyelamatkan sebuah keluarga.

Untuk bisa mencapai keseimbangan dalam pengambilan keputusan, diperlukan hubungan yang sistematis dengan Sang Pencipta. Bukankah Allah swt telah memastikan bahwa tidak ada masalah yang tak bisa diselesaiakan, dalam surah Al- Insyirah ayat 5-6.

"karena sesungguhnya sesudah kesulitan itu ada kemudahan (5) sesungguhnya sesudah kesulitan itu ada kemudahan (6)."

Aspek realigiusitas sangat dibutuhkan dalam kondisi ini. Financial distress merupakan salah satu bentuk ujian dari Sang Khalik. Ketika aspek religiusitas dimasukkan ke dalam solusi pemecahan masalah, maka keseimbangan antara manusia yang bersimphony dengan alam semesta akan mampu menghasilkan keputusan yang tepat, bukan keputusan yang terbaik untuk perusahaan saja tetapi keputusan yang terbaik untuk semua pihak yang terkait dengan perusahaan tersebut.

Menurut Cicero (Ismail, 1997), relegare berarti melakukan sesuatu perbuatan dengan penuh penderitaan, yakni jenis laku peribadatan yang dikerjakan berulang-ulang dan tetap.Dalam bahasa Arab, agama dikenal dengan kata al-din dan al-milah. Kata aldin sendiri mengandung berbagai arti. Ia bisa berarti al-mulk (kerajaan), al- 


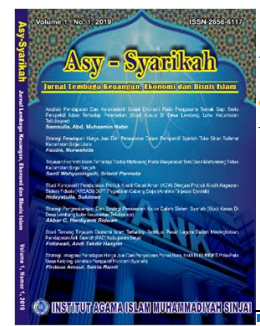

Asy-Syarikah

Jurnal Lembaga Keuangan, Ekonomi dan Bismis Islam

Volume 2, No. 2, 2020

ISSN (print) : 2656-6117

ISSN (online) : 2715-0356

Homepage : http://journal.iaimsinjai.ac.id/index.php/asy-syarikah

khidmat (pelayanan), al-izz (kejayaan), al-dzull (kehinaan), al-ikrah (pemaksaan), alihsan (kebajikan), al-adat (kebiasaan), al-ibadat (pengabdian), al-qahr wa alsulthan (kekuasaan dan pemerintahan), al-tadzallul wa al-khudu (tunduk dan patuh), altha'at (taat), al-islam al-tauhid (penyerahan dan mengesakan Tuhan) (Kahmad, 2002).

Dari istilah agama inilah kemudian muncul apa yang dinamakan religiusitas. Meski berakar kata sama, namun dalam penggunaannya istilah religiusitas mempunyai makna yang berbeda dengan religi atau agama. Kalau agama menunjuk pada aspek formal yang berkaitan dengan aturan-aturan dan kewajiban-kewajiban; religiusitas menunjuk pada aspek religi yang telah dihayati oleh individu di dalam hati (Mangunwijaya, 1982). Religiusitas seringkali diidentikkan dengan keberagamaan. Religiusitas diartikan sebagai seberapa jauh pengetahuan, seberapa kokoh keyakinan, seberapa pelaksanaan ibadah dan kaidah dan seberapa dalam penghayatan atas agama yang dianutnya. Bagi seorang Muslim, religiusitas dapat diketahui dari seberapa jauh pengetahuan, keyakinan, pelaksanaan dan penghayatan atas agama Islam (Fuad Nashori dan Rachmy Diana Mucharam, 2002).

Aspek religiusitas dikaitkan dengan personalitas perusahaan yaitu dengan meningkatkan habluminallah. Sinkronisasi ketenangan jiwa akan mempermudah seorang manager keuangan dalam membuat final decision.

Financial distress pada perusahaan dapat diatasi dengan beberapa cara yaitu :

1. Berhubungan dengan aset perusahaan yaitu dengan menjual aset-aset utama, melakukan merger dengan perusahaan lain, menurunkan pengeluaran dan biaya penelitian dan pengembangan.

2. Berhubungan dengan restrukturisasi keuangan yaitu dengan menerbitkan sekuritas baru, mengadakan negosiasi dengan bank dan kreditor, dan bankrut. Financial distress dapat melibatkan restrukturisasi aset ataupun restrukturisasi keuangan.

3. Meningkatkan kualitas ibadah khususnya sholat.

Gambar Tahap Financial Distress.

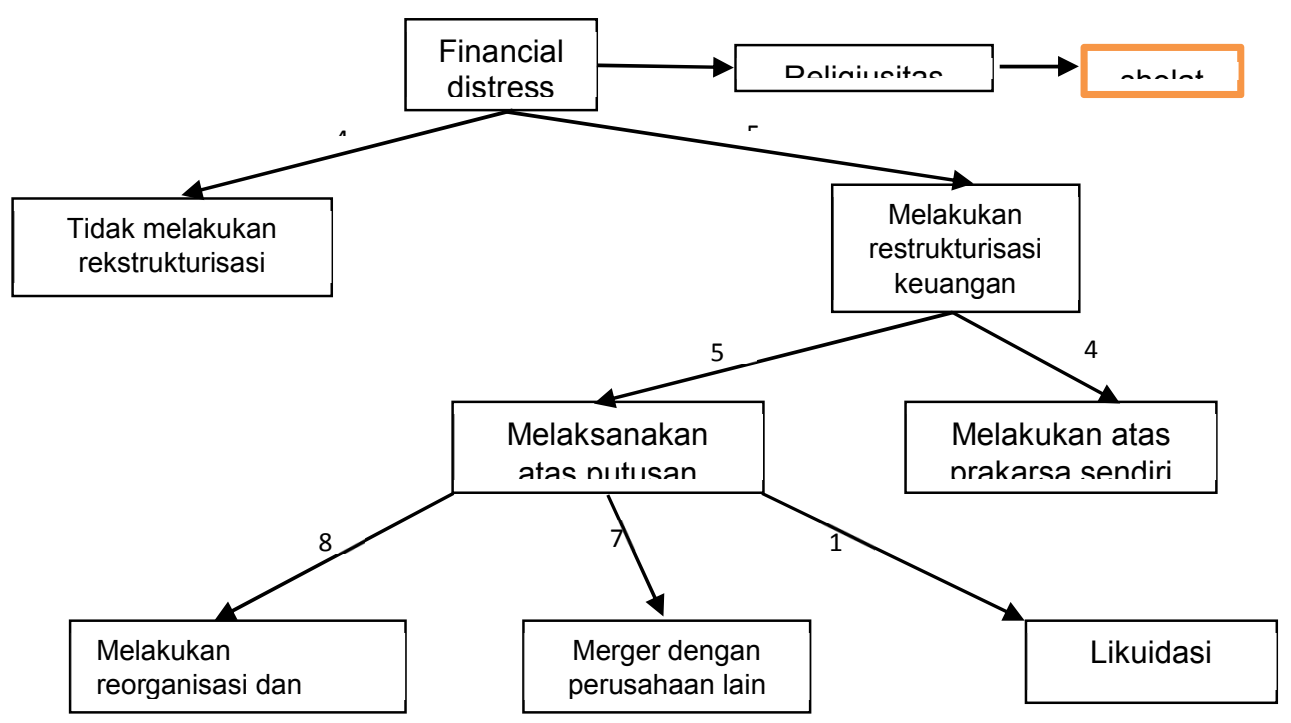

(Sumber : Ross, et.al. 2008. )

Gambar di atas menjelaskan tahap-tahap financial distress perusahaan sampai dengan kepada kebangkrutan.Sejumlah 51 persen perusahaan mendapatkan manfaat dari financial distress dengan merestrukturisasi aset mereka. Perusahaan yang tidak melakukan 


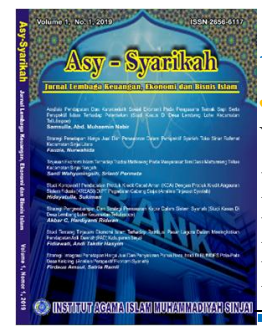

Asy-Syarikah

Jurnal Lembaga Keuangan, Ekonomi dan Bisnis Islam

Volume 2, No. 2, 2020

ISSN (print) : 2656-6117

ISSN (online) : 2715-0356

Homepage $\quad$ : http://journal.iaimsinjai.ac.id/index.php/asy-syarikah

restrukturisasi keuangan melakukan penyehatan terhadap hutang sehingga mengubah perilaku perusahaan dan mendesak perusahaan untuk membuang bisnis mereka yang tidak berhubungan. Hal ini terjadi pada perusahaan Goodyear Tire and Rubber, pada tahun 1986. Mereka memiliki cashflow perusahaan yang tidak cukup untuk menutupi pembayaran yang dibutuhkan dan mendesak mereka untuk menjual noncore bussinesses. Financial distress pada beberapa perusahaan membawa perusahaan kepada bentuk organisasi baru dan strategi operasi yang baru.

Restrukturisasi keuangan dapat dilakukan sendiri atau dilakukan atas putusan pengadilan. Dalam gambar tersebut dijelaskan juga, bahwa hampir separuh restrukturisasi atas prakarsa sendiri. Dan yang melaksanakan restrukturisasi berdasarkan putusan pengadilan sejumlah 83 persen dapat melakukan reorganisasi dan meneruskan usahanya kembali.Dari Shahabat Jabir bin 'Abdillah radhiyallahu 'anhu, beliau berkata,

"Rasulullah Shallallahu 'alaihi wa sallam, mengajari kami shalat istikharah dalam setiap perkara / urusan yang kami hadapai, sebagaimana beliau mengajarkan kami suatu surah dari Al-Quran. Beliau berkata, "Jika salah seorang di antara kalian berniat dalam suatu urusan, maka lakukanlah shalat dua raka'at yang bukan shalat wajib, kemudian berdoalah...". (HR. Al-Bukhari)

Financial distress dapat menjadi "early warning" system perusahaan sebagai tanda adanya masalah. Perusahaan yang memiliki banyak hutang akan mengalami financial distress lebih awal dari perusahaan yang memiliki sedikit hutang. Namun demikian perusahaan yang mengalami financial distress lebih awal dapat mempunyai banyak waktu untuk melakukan restrukturisasi atas prakarsa sendiri dan reorganisasi.

Secara umum kegiatan perusahaan dapat dianggap sebagai suatu proses arus dana. Dimulai dengan proses penarikan dana dari berbagai sumber kemudian dilakukan pembelanjaan dana tersebut pada harta perusahaan, lalu dilakukan pengoperasian atas harta perusahaan tersebut, dilanjutkan dengan reinvestasi dana yang diperoleh dari operasi perusahaan dan diakhiri dengan pengembalian. Dengan mendasarkan kepada pengertian arus dana ini dapat dikatakan bahwa financial distress merupakan keburukan dari bisnis perusahaan. Salah satu penyebab terjadinya financial distress adalah keburukan dalam pengelolaan bisnis (mismanagement) perusahaan tersebut. Namun demikian dengan bervariasinya kondisi internal dan eksternal maka terdapat banyak hal lain yang juga dapat menyebabkan terjadinya financial distress pada suatu perusahaan.

Apabila ditinjau dari aspek keuangan, maka terdapat tiga keadaan yang dapat menyebabkan financial distress yaitu :

1. Faktor ketidakcukupan modal atau kekurangan modal.

Ketidakseimbangan aliran penerimaan uang yang bersumber pada penjualan atau penagihan piutang dengan pengeluaran uang untuk membiayai operasi perusahaan tidak mampu menarik dana untuk memenuhi kekurangan dana tersebut, maka perusahaan akan berada pada kondisi tidak likuid.

2. Besarnya beban hutang dan bunga. Apabila perusahaan mampu menarik dana dari luar, misalnya mendapatkan kredit dari bank untuk menutup kekurangan dana, maka masalah likuiditas perusahaan dapat teratasi untuk sementara waktu. Tetapi kemudian timbul persoalan baru yaitu adanya keterikatan kewajiban untuk membayar kembali pokok pinjaman dan bunga kredit. Walaupun demikian hal ini tidak membahayakan perusahaan dan masih memberikan keuntungan bagi perusahaan apabila tingkat bunga lebih rendah dari tingkat investasi harta(Return on Asset) dan perusahaan melakukan apa yang disebut dengan manajemen resiko atas hutang yang diterimanya. 


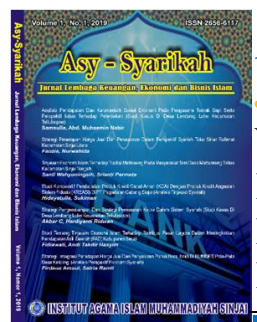

Asy-Syarikah

Jurnal Lembaga Keuangan, Ekonomi dan Bismis Islam

Volume 2, No. 2, 2020

ISSN (print) : 2656-6117

ISSN (online) : 2715-0356

Homepage : http://journal.iaimsinjai.ac.id/index.php/asy-syarikah

3. Manajemen resiko atas hutang ini sangat penting terutama apabila hutang yang diterima tidak dalam mata uang yang sama dengan pendapatan yang diperoleh perusahaan. Ketidakmampuan perusahaan melakukan manajemen resiko atas hutangnya dapat mengakibatkan perusahaan harus mendapatkan resiko menderita kerugian yang seharusnya tidak perlu terjadi.

4. Menderita Kerugian Pendapatan yang diperoleh perusahaan harus mampu menutup seluruh biaya yang dikeluarkan dan menghasilkan laba bersih. Besarnya laba bersih sangat penting bagi perusahaan untuk melakukan reinvestasi, sehingga akan menambah kekayaan bersih perusahaan dan meningkatkan ROE( Return on Equity ) untuk menjamin kepentingan pemegang saham. Oleh karena itu perusahaan harus selalu berupaya meningkatkan pendapatan dan mengendalikan tingkat biaya. Ketidakmampuan perusahaan mempertahankan keseimbangan pendapatan dengan biaya, niscaya perusahaan akan mengalami financial distress.

Ketiga aspek tersebut saling berkaitan. Oleh karena itu harus dijaga keseimbangannya agar perusahaan terhindar dari kondisi financial distress yang mengarah kepada kebangkrutan. Caranya adalah dengan kemampuan memperoleh laba, likuiditas dan tingkat hutang dalam struktur permodalan serta tak kalah pentingnya peningkatan nilai ibadah.

Kemampulabaan ( profitable) adalah kemampuan perusahaan untuk memperoleh laba yang cukup dari modal yang digunakan. Jadi setiap pendapatan harus menghasilkan laba kotor (gross profit) jauh diatas biaya operasional agar menghasilkan laba kotor sisa yang disebut laba bersih ( net profit). Setiap laba bersih kemudian harus diinvestasikan perusahaan guna memperbesar dana perusahaan.

Manajemen risiko atas hutang ini sangat penting terutama apabila hutang yang diterima tidak dalam mata uang yang sama dengan pendapatan yang diperoleh perusahaan. Ketidakmampuan perusahaan melakukan manajemen risiko atas hutangnya dapat mengakibatkan perusahaan harus mendapatkan risiko menderita kerugian yang seharusnya tidak perlu terjadi.

Likuiditas adalah kemampuan perusahaan untuk membiayai kegiatan operasional perusahaan dan membayar kewajiban jangka pendeknya dengan harta lancarnya terutama kas. Oleh karena itu perusahaan harus menjaga kualitas dan tingkat investasi piutang dan persediaan dalam arti kecepatan mengubah kas dengan risiko yang paling kecil.Untuk memprediksi kondisi financial distress perusahaan, salah satu caranya dengan mencari informasi dari laporan keuangan perusahaan.

\subsection{Rasio-Rasio Keuangan}

Laporan keuangan berisi informasi untuk masyarakat, pemerintah, pemasok dan kreditur, pemilik perusahaan atau pemegang saham, manajemen perusahaan, investor, pelanggan dan karyawan, yang diperlukan secara tetap untuk mengukur kondisi dan efisiensi operasi perusahaan. Analisa dari laporan keuangan bersifat relatif karena didasarkan pengetahuan dan menggunakan rasio atau nilai relatif analisa rasio adalah suatu metode perhitungan dan interprestasi rasio keuangan untuk menilai kinerja dan status suatu perusahaan . Beberapa rasio keuangan yang dapat mempengaruhi kondisi financial distress perusahaan adalah 1) Rasio Likuiditas, 2) Rasio Leverage, 3) Rasio Profit Margin, 4) Rasio Profitabilitas, 5) Rasio Aktivitas, 6) Ukuran Perusahaan, 7) Trend Harga Saham, 8) Return Saham.

\subsection{Faktor Ekonomi Makro Penyebab Financial Distress}

Ketidakpastian kondisi perekonomian suatu negara merupakan salah satu penyebab terjadinya financial distress. (Bringham,1997 dalam Fithrawati,2001). Ross 


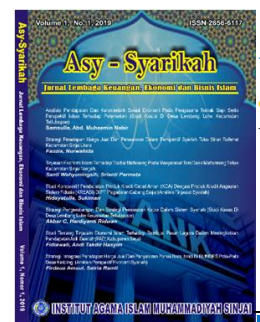

Asy-Syarikah

Jurnal Lembaga Keuangan, Ekonomi dan Bismis Islam

Volume 2, No. 2, 2020

ISSN (print) : 2656-6117

ISSN (online) : 2715-0356

Homepage : http://journal.iaimsinjai.ac.id/index.php/asy-syarikah

(2005), mengungkapkan bahwa ketidakpastian kondisi ekonomi makro, merupakan contoh dari risiko sistematis yang mempengaruhi sejumlah besar aset perusahaan. Kondisi ini mempengaruhi semua saham diberbagai tingkatan. Kepekaan perusahaan terhadap tekanan kondisi ekonomi makro merupakan inti dari risiko sistematis. Seperti dijelaskan sebelumnya bahwa return saham mempengaruhi financial distress perusahaan. Penyebab turunnya return saham, yaitu kepekaan perusahaan terhadap tekanan kondisi ekonomi makro ini merupakan penyebab dari financial distress perusahaan. Beberapa penjelasan terkait dengan faktor ekonomi makro adalah sebagai berikut :

1. Indeks Harga Saham Gabungan (IHSG)

IHSG pertama kali diperkenalkan pada tanggal 1 April 1983 sebagai indikator pergerakan harga saham yang tercatat di Bursa, baik saham biasa maupun saham preferen. Seperti penghitungan indeks di bursa lainnya. Indeks-indeks BEI adalah menggunakan rata-rata tertimbang dari nilai pasar (market value weight average index).

Rumus dasar penghitungan adalah sebagai berikut :

$$
\mathrm{IHSG}=\frac{\text { NIlai pasar }}{\text { Nilai dasar }} \times 100
$$

Nilai pasar adalah kumulatif jumlah saham hari ini dikali harga pasar hari ini ( Kapitalisasi pasar )

Nilai dasar adalah kumulatif jumlah saham pada hari dasar dikali harga dasar pada hari dasar. Hari dasar untuk IHSG adalah pada tanggal 10 Agustus 1982 dengan nilai 100.Indeks pasar ini merupakan alat ukur kinerja sekuritas khususnya saham yang listing di bursa yang digunakan oleh bursa-bursa di dunia. IHSG digunakan untuk mengukur kinerja saham. Fungsinya juga sebagai benchmark kinerja portofolio, indikator trend pasar, indikator tingkat keuntungan dan sebagai fasilitas perkembangan produk derivatif.

\subsection{Inflasi}

Dalam ekonomi, inflasi memiliki pengertian suatu proses meningkatnya hargaharga secara umum dan terus-menerus. Dengan kata lain, inflasi merupakan proses suatu peristiwa dan bukan tinggi-rendahnya tingkat harga. Artinya harga yang dianggap tinggi belum tentu menunjukan inflasi, dianggap inflasi jika terjadi proses kenaikan harga yang terus-menerus dan saling mempengaruhi.Inflasi merupakan faktor risiko yang harus dipertimbangkan dalam proses investasi. Adanya kenaikan harga secara umum akan berdampak pada berkurangannya daya beli sehingga tingkat hasil riil akan turun. Dengan demikian apabila inflasi naik, maka investor akan menginginkan kenaikan hasil nominal guna melindungi tingkat inflasi riilnya.

Inflasi dapat digolongkan menjadi empat golongan, yaitu inflasi ringan, sedang, berat dan hiperinflasi. Inflasi ringan terjadi apabila kenaikan harga berada dibawah angka 10 persen setahun; inflasi sedang antara 10 persen sampai dengan 30 persen setahun; inflasi berat antara 30 persen sampai dengan 100 persen setahun dan hiperinflasi atau inflasi tak terkendali terjadi apabila kenaikan harga berada diatas 100 persen setahun.

\subsection{Nilai Tukar}

Globalisasi mendorong investasi lintas negara disamping untuk tujuan diversifikasi. Oleh karena itu, risiko nilai mata uang merupakan faktor ketidakpastian yang dihadapi investor apabila melakukan investasi di pasar global. Dengan terbukanya peluang 


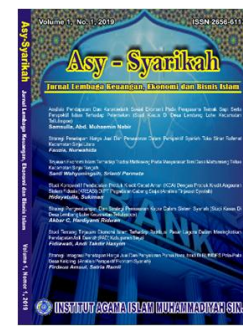

Asy-Syarikah

Jurnall Lembaga Keuangan, Ekonomi dan Bismis Islam

Volume 2, No. 2, 2020

ISSN (print) : 2656-6117

ISSN (online) : 2715-0356

Homepage : http://journal.iaimsinjai.ac.id/index.php/asy-syarikah

investasi di Bursa Efek Indonesia bagi investor asing, maka faktor nilai tukar US Dollar terhadap rupiah merupakan faktor risiko yang patut diperhitungkan. Semakin tinggi fluktuasi nilai tukar mata uang yang bersangkutan. Dengan demikian investor harus mempertimbangkan pula premi risiko atas nilai tukar tersebut.

Nilai tukar rupiah terhadap US Dollar mempunyai hubungan positif dan signifikan mempengaruhi return saham. Dan return saham mempengaruhi kondisi financial distress perusahaan, maka dapat diasumsikan bahwa sensitifiats perusahaan terhadap nilai tukar mempengaruhi kondisi financial distress perusahaan.

\subsection{Islamic Financial Distress}

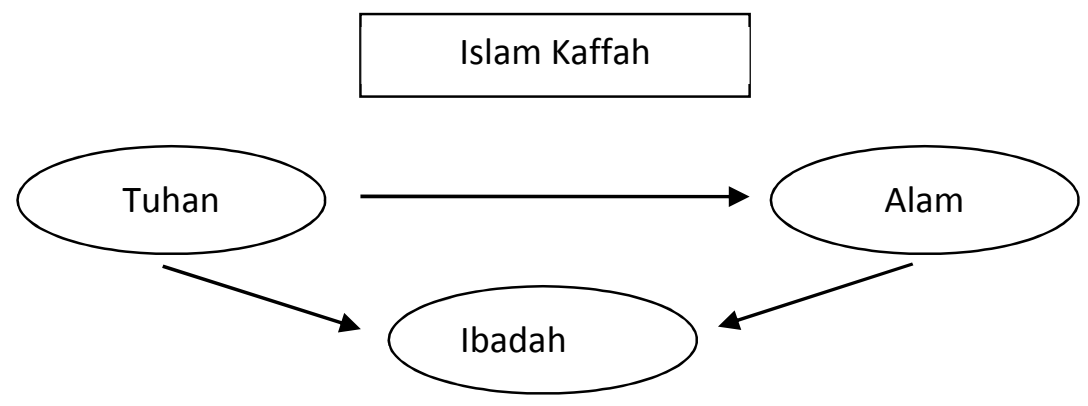

(Sumber : Islam dan Pengetahuan. 2018)

Berdasarkan pada pendekatan Teori $\mathrm{H}$ dalam kaitannya dengan financial distress, ketiga elemen di atas dikonversikan ke elemen lain yang merupakan faktor penentu financial distress yaitu elemen Tuhan menjadi elemen Modal, elemen Ibadah menjadi aktifitas, dan elemen Alam menjadi Profit.

Modal merupakan hal paling penting dalam sebuah perusahaan yang tak bisa digantikan oleh hal lain, modal adalah titik awal yang harus selalu ada dalam perusahaan. Aktifitas perusahaan yang aktif dan positif akan menambah nilai modal awal yang selanjutnya terakumulasi ke profit. Sinergi dari ketiga elemen ini menyerupai ketiga elemen islam kaffah.

Ketika elemen Tuhan di hilangkan atau dikurangi maka ibadah akan berkurang, kemampuan untuk berinteraksi dengan alam akan berkurang pula, sehingga segala potensi dari hubungan ketiga elemen ini akan tetap diam. Faktor-faktor financial distress yang merupakan konversi dari ketiga elemen tersebut akan mengalami hal yang sama ketika pelaku bisnis tidak memasukkan unsur religiousitas ke dalam 3 elemen ini. Sinergi dari Modal, Aktifitas, dan Profit akan seimbang ketika memasukkan susbtansi peran Sang Pencipta. Dia lah yang Maha Mengetahui atas segala yang terjadi di muka bumi ini. Tuhan telah memberi hadiah kepada umat manusia atas segala masalahnya yaitu melalui sholat. Mintalah padaNya melalui sujud dalam sepertiga malam, bahkan alam semesta pun akan turut meringankan masalah tersebut.

Oleh karna itu pentingnya aspek realigiusitas pada financial distress akan diuraikan dalam fungsi berikut.

\section{Fungsi}

Berangkat dari Teorema Kekongruenan, dimana $\mathrm{M}>0, \mathrm{~A}>0, \mathrm{P}>0$.

$\mathrm{F} \equiv \mathrm{M}(\bmod \mathrm{m})$

$\mathrm{F} \equiv \mathrm{A}(\bmod \mathrm{m})$

$\mathrm{F}=\mathrm{mk}+\mathrm{M}$

$\mathrm{F}=\mathrm{mk}+\mathrm{A}$ 


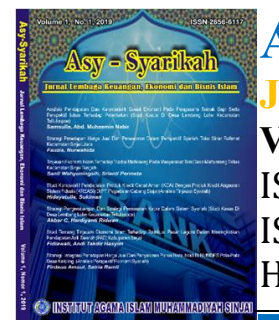

Asy-Syarikah

Jurnal Lembaga Keuangan, Ekonomi dan Bisnis Islam

Volume 2, No. 2, 2020

ISSN (print) : 2656-6117

ISSN (online) : 2715-0356

Homepage : http://journal.iaimsinjai.ac.id/index.php/asy-syarikah

$\mathrm{F} \equiv \mathrm{P}(\bmod \mathrm{m})$

3)

$\mathrm{F}=\mathrm{mk}+\mathrm{P}$

Maka

$f: F=S(M, A, P)$

Keterangan:

$\mathrm{m}=$ bilangan positif, $\mathrm{k}=$ bilangan bulat, $\mathrm{M}=$ Modal, $\mathrm{A}=$ Aktivitas, $\mathrm{P}=$ Profit, $\mathrm{U}=\mathrm{Utang}$

$F=m \cdot k+M$

$F=m \cdot k+A$

$F=m \cdot k+P$

$F=m \cdot k+M+A+P$

$F=m . k+M+A+P$......konvensional

$\mathrm{m} . \mathrm{K}=$ Konstanta

$F=S+M+A+P+e$

..islamic

$\mathrm{S}=$ Sholat

Dalam hal ini digunakan pendekatan kekongruenan dalam modulo, dimana akan selalu ada sisa pembagian dari setiap fungsi. Fungsi di atas berarti bahwa faktor-faktor financial distress yaitu modal, aktivitas, dan profit harus $>0$, ketika ketiga faktor di atas bernilai $<0$ maka hal itu dapat memicu financial distress. $\mathrm{M} \neq 0, \mathrm{Ai} \neq 0$, dan $\mathrm{P} \neq 0$.

\begin{tabular}{|c|c|c|c|c|c|c|c|c|c|c|c|c|c|c|c|c|}
\hline H & $=$ & A0 & $\mathbf{x}$ & a1 & $\mathbf{x}$ & H & + & a2 & $\mathbf{X}$ & S0 & + & a3 & $\mathbf{x}$ & L3 & + & M \\
\hline $\bar{Y}$ & $=$ & $\mathrm{a} 0$ & + & a1 & $\bar{x}$ & $\mathrm{X} 1$ & + & $\mathrm{a} 2$ & $\bar{X}$ & $\mathrm{X} 3$ & + & a3 & $\bar{x}$ & $\mathrm{X} 3$ & + & $\mathbf{E}$ \\
\hline $\begin{array}{l}\text { Variabel } \\
\text { dependent }\end{array}$ & $=$ & $\begin{array}{c}\text { Konstan } \\
\text { ta }\end{array}$ & + & Koefisien & $\mathrm{x}$ & $\begin{array}{c}\text { Variabel } \\
1\end{array}$ & + & koefisien & X & $\begin{array}{c}\text { Variabel } \\
2\end{array}$ & + & Koefisien & $\mathrm{x}$ & $\begin{array}{c}\text { variabel } \\
3\end{array}$ & + & $\mathbf{E}$ \\
\hline $\begin{array}{l}\text { Financial } \\
\text { Distress }\end{array}$ & $=$ & sholat & + & Koefisien & $x$ & Modal & + & koefisien & $X$ & Aktifitas & + & koefisien & $\mathrm{x}$ & Profit & + & $\mathbf{E}$ \\
\hline
\end{tabular}

Sholat menjadi sebuah konstanta mutlak yang harus selalu ada. Untuk mencegah efek terburuk dari financial distress, sholat adalah solusi terbaik. Salah satu istilah belum lama ini telah dikaitkan dengan sholat Tahajjud dan terapi kesehatan adalah Psikoneuroimunologi (PNI). Psikoneuroimunologi (PNI) adalah suatu cabang ilmu kedokteran yang mengkaji interaksi antara faktor stres psikologis yang mempengaruhi respon imun, pengaruh stres psikologis terhadap perubahan respons imun serta manifestasi berbagai penyakit yang diperantarai oleh sistem imun. Secara sederhana Psikoneuroimunologi (PNI) dapat diartikan sebagai bentuk kekebalan tubuh yang didapat dari kondisi psikologi dan keadaan jiwa seseorang.Atau bisa juga diartikan sebagai hubungan antara keadaan otak/saraf, pkisis dan kekebalan tubuh seseorang. Jadi, secara Psikoneuroimunologis kesehatan seseorang akan terganggu ketika ada gangguan pada aspek psikologis. 


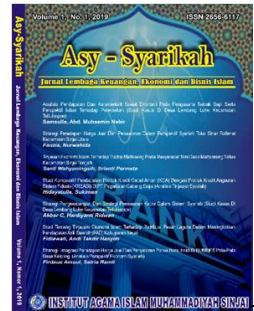

\section{Asy-Syarikah}

Jurnal Lembaga Keuangan, Ekonomi dan Bisnis Islam

Volume 2, No. 2, 2020

ISSN (print) : 2656-6117

ISSN (online) : 2715-0356

Homepage : http://journal.iaimsinjai.ac.id/index.php/asy-syarikah

Pada saat salat Tahajud, kita terbawa pada suatu kondisi emosional yang stabil.

Emosi yang stabil akan mempermudah dalam berpikir, bertindak, dan berinteraksi.

Sehingga dalam membuat keputusan akan nampak perbedaan dalam pelaksanaannya.

\subsection{Penerapan Islamic Financial}

Distress Berdasarkan laporan keuangan yang penulis dapat dari annual report PT.CIMB NIAGA,Tbk dari tahun 2007 hingga 2011 , maka penulis memperingkas data yang dibutuhkan dalam menghitung Altman Z Score, seperti yang tertera di dalam tabel Dimana elemen-elemen dari laporan keuangan yang diperlukan dalam perhitungan Altman Z Score adalah :

1) modal kerja(working capital) yang mana modal kerja didapat dari perhitungan aktiva lancar dikurangi dengan kewajiban lancar, kedua elemen ini terdapat dalam neraca

2) Total aktiva ( total assets) yang mana total aktiva ini adalah elemen laporan keuangan yang terdapat pada neraca .

3) Laba ditahan (retained earning), elemen ini terdapat pada perubahan modal.

4) Laba sebelum bunga dan pajak ( $E B I T$ ), elemen ini terdapat pada laba rugi .

5) Nilai buku utang (Book Value of Total Liabilities), elemen ini terdapat pada neraca dimana nilai buku utang sendiri didapat dari kewajiban lancar ditambah dengan kewajiban tidak lancar .

Tabel 4.1

Data Ringkasan Laporan KeuanganPT BANK CIMB NIAGA ,Tbk. (Jutaan Rupiah)

\begin{tabular}{|l|l|l|l|l|l|}
\hline Keterangan & $\mathbf{2 0 0 7}$ & $\mathbf{2 0 0 8}$ & $\mathbf{2 0 0 9}$ & $\mathbf{2 0 1 0}$ & $\mathbf{2 0 1 1}$ \\
\hline Aktiva lancer & $\mathbf{7 4 . 0 0 4 . 7 2 1}$ & $\mathbf{1 8 . 7 7 8 . 9 6 8}$ & $\mathbf{1 7 . 3 5 3 . 1 4 2}$ & $\mathbf{3 3 . 7 0 8 . 3 7 8}$ & $\mathbf{3 3 . 6 7 7 . 1 5 9}$ \\
\hline Kewajiban lancar & $\mathbf{8 1 . 6 6 6 . 4 9 7}$ & $\mathbf{9 0 . 2 7 3 . 1 9 2}$ & $\mathbf{9 0 . 4 7 7 . 6 1 9}$ & $\mathbf{1 2 2 . 2 9 8 . 4 1 4}$ & $\mathbf{1 3 9 . 9 1 2 . 4 6 2}$ \\
\hline Working capital & $-\mathbf{7 . 6 6 1 . 7 7 6}$ & $\mathbf{- 7 1 . 4 9 4 . 2 2 4}$ & $\mathbf{- 7 3 . 1 2 4 . 4 7 7}$ & $\mathbf{- 8 8 . 5 9 0 . 0 3 6}$ & $\mathbf{- 1 0 6 . 2 3 5 . 3 0 3}$ \\
\hline Total asset & $\mathbf{9 3 . 7 9 7 . 1 8 9}$ & $\mathbf{1 0 3 . 1 9 7 . 5 7 4}$ & $\mathbf{1 0 7 . 1 0 4 . 2 7 4}$ & $\mathbf{1 4 3 . 6 5 2 . 8 5 2}$ & $\mathbf{1 6 6 . 8 0 1 . 1 3 0}$ \\
\hline Retained earning & $\mathbf{1 . 8 5 6 . 1 7 6}$ & $\mathbf{2 . 5 4 4 . 7 3 0}$ & $\mathbf{3 . 6 7 2 . 0 5 2}$ & $\mathbf{6 . 0 0 0 . 4 1 9}$ & $\mathbf{8 . 9 7 4 . 7 6 8}$ \\
\hline EBIT & $\mathbf{6 . 1 4 1 . 5 3 8}$ & $\mathbf{6 . 3 1 7 . 7 9 4}$ & $\mathbf{7 . 3 2 6 . 6 4 9}$ & $\mathbf{8 . 5 1 1 . 6 4 1}$ & $\mathbf{7 . 2 9 6 . 2 4 6}$ \\
\hline Book Value of Equity & $\mathbf{9 . 0 8 1 . 8 7 5}$ & $\mathbf{9 . 3 0 2 . 4 6 7}$ & $\mathbf{1 1 . 2 7 6 . 3 7 2}$ & $\mathbf{1 3 . 8 4 0 . 5 0 0}$ & $\mathbf{1 8 . 3 6 9 . 4 9 1}$ \\
\hline $\begin{array}{l}\text { Book } \\
\text { ofTotalLiabilities }\end{array}$ & $\mathbf{8 4 . 6 6 1 . 4 4 4}$ & $\mathbf{9 3 . 8 3 6 . 3 4 6}$ & $\mathbf{9 5 . 8 2 7 . 9 0 2}$ & $\mathbf{1 2 9 . 8 1 2 . 3 5 2}$ & $\mathbf{1 4 8 . 4 3 1 . 6 3 9}$ \\
\hline $\begin{array}{l}\text { Sholat Tahajjud } \\
\text { Value }\end{array}$ & $\mathbf{K}$ & $\mathbf{k}$ & $\mathbf{K}$ & $\mathbf{k}$ & $\mathbf{k}$ \\
\hline
\end{tabular}

(Sumber : Laporan Keuangan di lampiran)

Perhitungan Altman Z Score PT.CIMB NIAGA,Tbk

Rumus Altman Z Score $=6.56 X_{1}+6.72 X_{4}+3.26 X_{2}+1.05 X_{3}$

Dimana :

$\mathrm{X}_{1}$ : Modal Ratio

$\mathrm{X}_{4}$ : Aktifitas Ratio 
$\mathrm{X}_{2}$ : Profit Ratio

$\mathrm{X}_{3}$ : Profit Ratio

Di bawah ini adalah hasil perhitungan yang penulis lakukan dengan menggunakan metode Altman Z Score .

Setelah mengetahui hasil nilai Altman Z Score, maka akan tampak " kesehatan "suatu perusahaan. Untuk membedakan perusahaan yang memprediksi akan bangkrut atau tidak maka diperlukan nilai cut off (nilai patokan) . Ada 3 nilai cut off, diantaranya :

a. untuk nilai Z-Score lebih kecil atau sama dengan 1,81 berarti perusahaan mengalami kesulitan keuangan dan risiko tinggi.

b. untuk nilai Z-Score antara 1,81 sampai 2,99, perusahaan dianggap berada pada daerah abu-abu (grey area). Pada kondisi ini, perusahaan mengalami masalah keuangan yang harus ditangani dengan penanganan manajemen yang tepat.Jika terlambat dan tidak tepat penangannya, perusahaan dapat mengalami kebangkrutan. Jadi pada grey area ini ada kemungkinan perusahaan bangkrut dan ada pula yang tidak tergantung bagaimana pihak manajemen perusahaan dapat segera mengambil tindakan untuk segera mengatasi masalah yang dialami oleh perusahaan.

c. untuk nilai Z-Score lebih besar dari 2,99 memberikan penilaian bahwa perusahaan berada dalam keadaan yang sangat sehat sehingga kemungkinan kebangkrutan sangat kecil terjadi.

Sedangkan untuk perusahaan non manufaktur nilai cut off nya antara lain :

a. $\mathrm{Z}<1,23$ - Perusahaan berpotensi kuat akan mengalami kebangkrutan

b. $1,23 \geq Z$-Score $\leq 2,90$ - Terdapat kondisi keuangan di suatu bagian yang membutuhkan perhatian khusus

c. Altman Z Score $>2,90$ - Berdasarkan laporan keuangan, perusahaan dianggap aman Dalam hal ini, ibadah bertindak sebagai konstanta, bukanlah rasio. Sehingga ketika dimasukkan ke dalam persamaan akan menjadi seperti berikut:

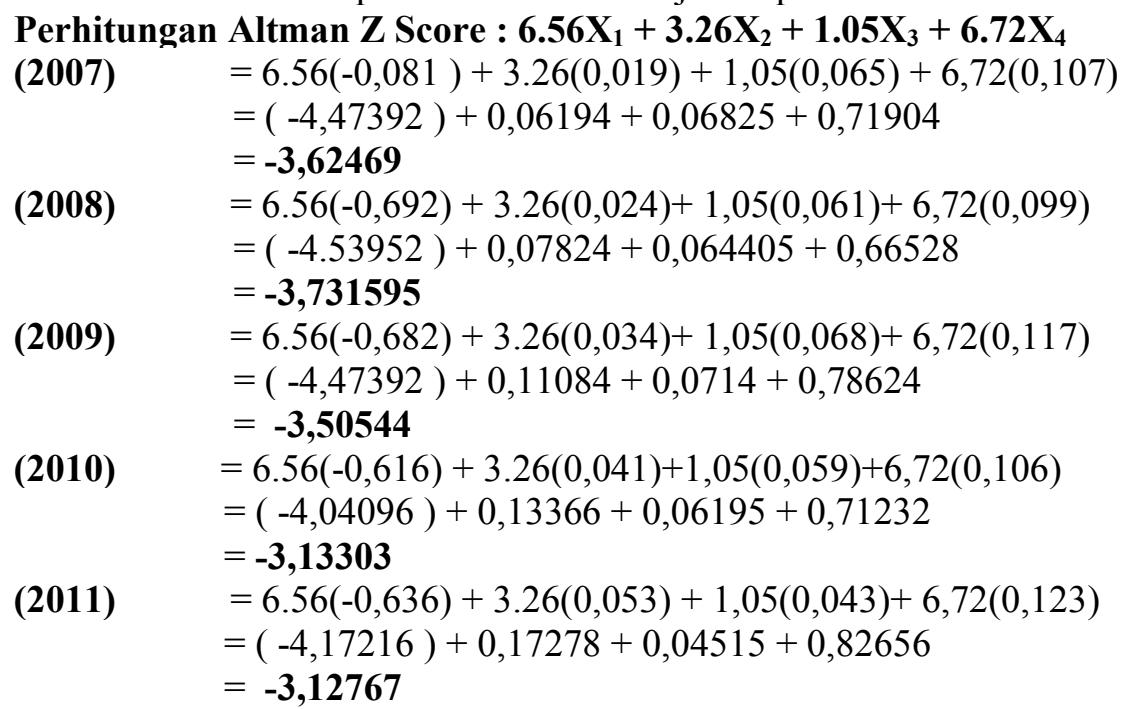

Setelah diadakan perhitungan seperti diatas maka didapatkan hasil prediksi yang penulis buat dalam table dan grafik agar dapat lebih memperjelas dan mempermudah penulis dalam melihat perkembangan nilai Altman Z Score dari tahun 2007 hingga 2011 . Dimana table dan grafiknya adalah sebagai berikut :

Tabel 4.2

Hasil Perhitungan Altman Z Score PT.CIMB NIAGA,Tbk 


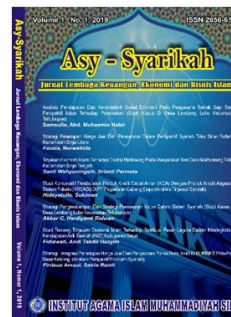

\section{Asy-Syarikah}

Jurnall Lembaga Keuangan, Ekonomi dan Bisnis Islam

Volume 2, No. 2, 2020

ISSN (print) : 2656-6117

ISSN (online) : 2715-0356

Homepage : http://journal.iaimsinjai.ac.id/index.php/asy-syarikah

Tabel di atas adalah table penggolongan atas keadaan perusahaan yang dilihat dari

\begin{tabular}{|l|l|l|}
\hline Tahun & Hasil Altman Z Score & Prediksi Altman Z Score \\
\hline 2007 & $\mathbf{- 3 , 6 2 4 6 9}$ & Berisiko Pailit \\
\hline 2008 & $\mathbf{- 3 , 7 3 1 5 9 5}$ & Berisiko Pailit \\
\hline 2009 & $\mathbf{- 3 , 5 0 5 4 4}$ & Berisiko Pailit \\
\hline 2010 & $\mathbf{- 3 , 1 3 3 0 3}$ & Berisiko Pailit \\
\hline 2011 & $\mathbf{- 3 , 1 2 7 6 7}$ & Berisiko Pailit \\
\hline
\end{tabular}

hasil perhitungan Altman Z Score apakah masuk dalam keadaaan aman ataukah dalam keadaan perlu perhatian khusus atau dalam keadaaan resiko pailit. Keadaan di atas menerangkan bahwa perusahaan tersebut dalam keadaan resiko pailit. Kita akan melihat perbandingan keadaan perusahaan tersebut ketika nilai ibadah dimasukkan. Penambahan $\mathrm{k}$ digunakan untuk mewakili intensitas peningkatan nilai sholat pelaku pengambil keputusan. Ketika nilai ibadahnya meningkat maka secara langsung akan menggunakan $\mathrm{k}$ sebagai konstanta dimana $\mathrm{k}>0, \mathrm{k} \in$ bilangan bulat. Jumlah ibadah/sholat tidak bisa menjamin peningkatan ibadah seseorang, karna manusia sebagai pelaku bahkan belum bisa menjamin apakah ibadah tersebut terhitung sebagai amalan yang telah diterima atau tidak. Oleh karna itu, penggunaan angka 1 dalam hal ini sebagai nilai yang mewakili usaha manusia dalam beribadah

Persamaan $=k+6.56 X_{1}+3.26 X_{2}+1.05 X_{3}+6.72 X_{4}+e$

$\mathrm{k}=$ nilai islam (Sholat)

Untuk $k=1$

Altman Z Score S (2007) $\quad=1+(-3,62469)$

$$
=-2,62469
$$

Altman Z Score S (2008) $\quad=1+(-3,731595)$

$$
=-2,731595
$$

Altman Z Score S (2009) $\quad=1+(-3,50544)$

$$
=-2,50544
$$

Altman Z Score S (2010) $\quad=1+(-3,13303)$

$$
=-2,13303
$$

Altman Z Score S (2011) = $1+(-3,12767)$

$$
=-2,12767
$$

\begin{tabular}{|l|l|l|}
\hline Tahun & Hasil Altman Z Score & Prediksi Altman Z Score \\
\hline 2007 & $\mathbf{- 2 , 6 2 4 6 9}$ & Berisiko Pailit \\
\hline 2008 & $\mathbf{- 2 , 7 3 1 6}$ & Berisiko Pailit \\
\hline 2009 & $\mathbf{- 2 , 5 0 5 4 4}$ & Berisiko Pailit \\
\hline 2010 & $\mathbf{- 2 , 1 3 3 0 3}$ & Berisiko Pailit \\
\hline 2011 & $\mathbf{- 2 , 1 2 7 6 7}$ & Berisiko Pailit \\
\hline
\end{tabular}

Ketika nilai ibadah dimasukkan, keadaan perusahaan tersebut masih di dalam standar berisiko pailit namun, nilai Altman Z Score terlihat bertambah. 


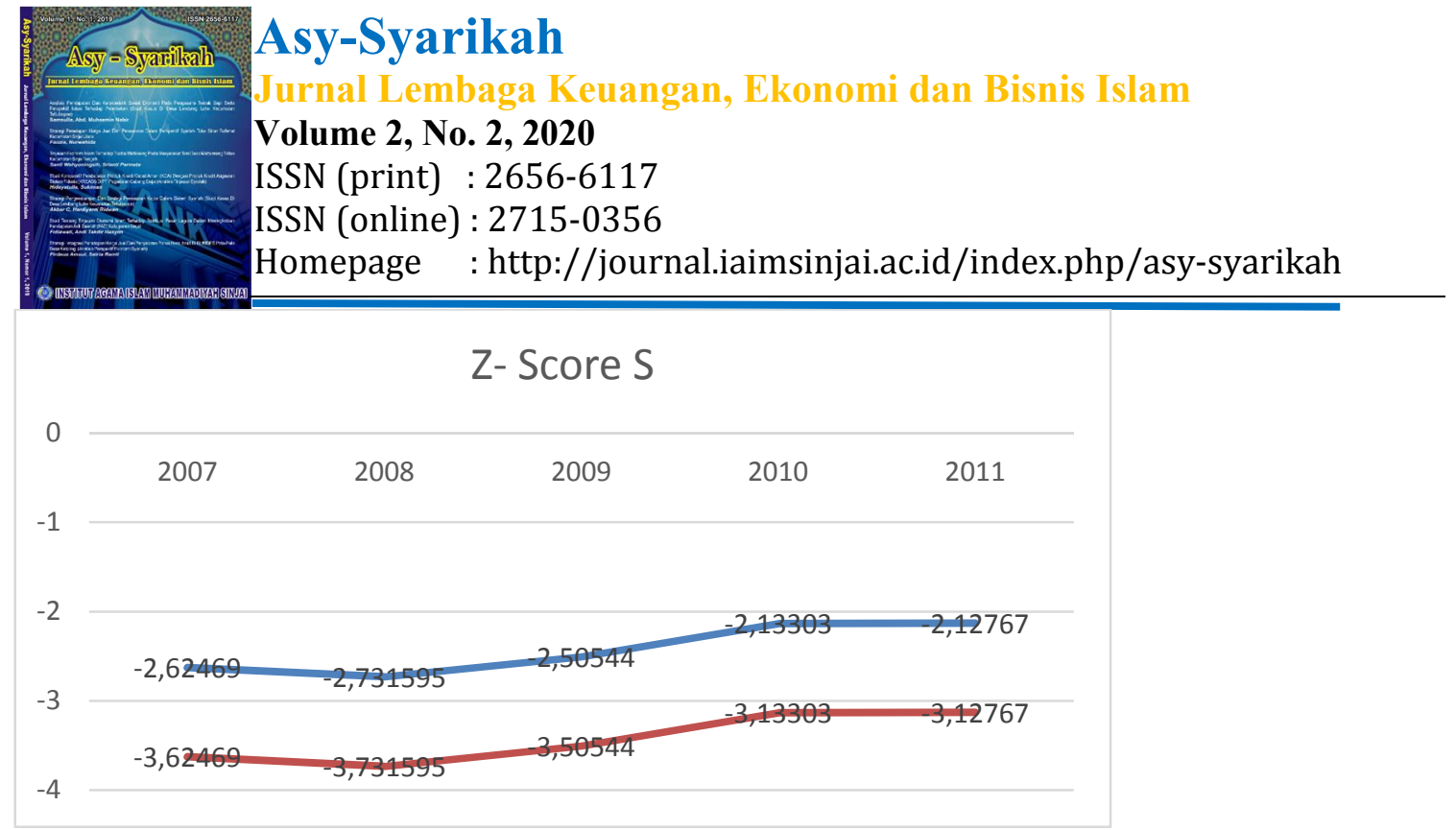

Nilai ibadah dalam hal ini dapat menaikkan rasio Z-Score. Sehingga dalam suatu keadaan, dimana perusahaan yang harusnya berada dalam cut-off ke-3 dengan adanya penambahan dari nilai ibadah tersebut, perusahaan dapat masuk ke dalam kategori cut off ke-2 demikian pula selanjutnya. Keadaan perusahaan tersebut semakin jauh dari kebankrutan.

\section{Kesimpulan}

1. Sebuah Perusahaan agar terhindar dari kondisi financial distress yang mengarah kepada kebangkrutan. Maka dapat dipertahankan dengan cara kemampuan memperoleh laba, likuiditas dan tingkat hutang dalam struktur permodalan serta tak kalah pentingnya peningkatan nilai ibadah. return saham mempengaruhi financial distress perusahaan. Penyebab turunnya return saham, yaitu kepekaan perusahaan terhadap tekanan kondisi ekonomi makro ini merupakan penyebab dari financial distress perusahaan.

2. Ditinjau dari aspek keuangan, terdapat tiga keadaan yang dapat menyebabkan financial distress yaitu:

a. Faktor ketidakcukupan modal atau kekurangan modal. Ketidakseimbangan aliran penerimaan uang yang bersumber pada penjualan atau penagihan piutang dengan pengeluaran uang untuk membiayai operasi perusahaan tidak mampu menarik dana untuk memenuhi kekurangan dana tersebut, maka perusahaan akan berada pada kondisi tidak likuid.

b. Besarnya beban hutang dan bunga.

c. Manajemen resiko atas hutang ini sangat penting terutama apabila hutang yang diterima tidak dalam mata uang yang sama dengan pendapatan yang diperoleh perusahaan. Ketidakmampuan perusahaan melakukan manajemen resiko atas hutangnya dapat mengakibatkan perusahaan harus mendapatkan resiko

\section{Daftar Pustaka} menderita kerugian yang seharusnya tidak perlu terjadi.

Ali, Herni \& Ahmad Rodhoni. (2014). Manajemen Keuangan Modern. Jakarta :Mitra Wacana Media

Aziz, Roikhan Mochamad. 2004. Islamic Micro Macro Economics. Module 1, Jakarta: UIN Syarif Hidayatullah.

Aziz, Roikhan Mochamad. 2005. Sinlammim Kode Tuhan. Esa Alam, Jakarta. Aziz, Roikhan Mochamad. 2006. Jejak Islam Yang Hilang. Sinlammim, Jakarta. Aziz, Roikhan Mochamad. 2008. Analisis Pemodelan Sukuk Indonesia Malaysia Dengan System Dynamics. Disertasi, Sekolah Pasca Sarjana, Universitas Islam Negeri Syarif Hidayatullah, Jakarta. 


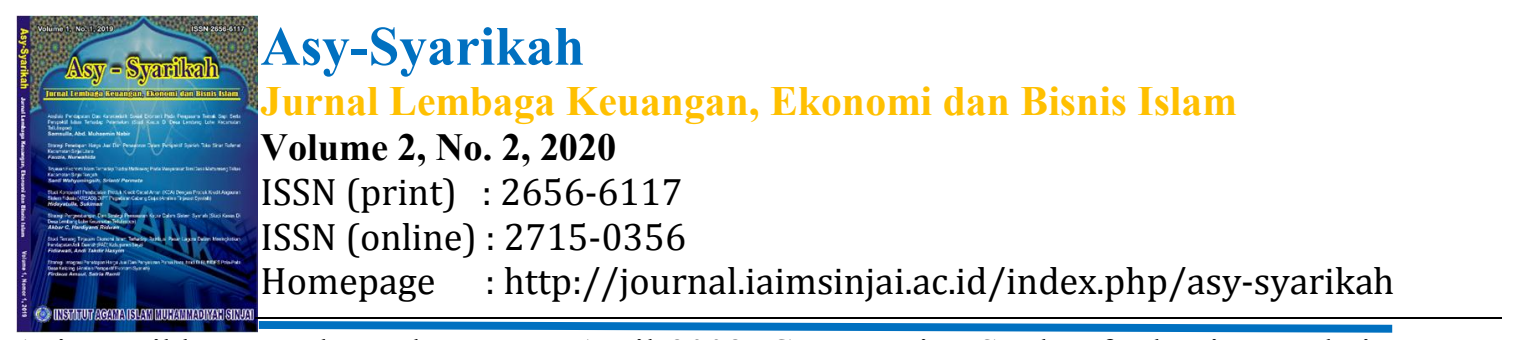

Aziz, Roikhan Mochamad. January-April 2008. Comparative Study of Islamic Bonds in Indonesia and Malaysia on System Dynamics Approach. Jurnal Ekonomi Kemasyarakatan Equilibirium, Vol,5, No. 2 Jakarta. http://www.stiead.ac.id.

Aziz, Roikhan Mochamad. August 2008. Kaffah Approach In Islamic Economics Theory. Journal.University Islamic Indonesia (UII), Jogjakarta, Indonesia.

Aziz, Roikhan Mochamad. August 2008. Holistic Thinking To Develop Islamic Bonds In Indonesia. Proceeding. IAEI - University Airlangga (Unair), Surabaya, Indonesia.

Aziz, Roikhan Mochamad. September 2008. Sukuk Dynamics In System Thinking. School Of Business (SBM), Institute Technology Bandung (ITB), Bandung, Indonesia.

Aziz, Roikhan Mochamad. October 2008. The Application Of Mathematics In Information System Based On Al-Quran. Working Paper, Studium General, State Islamic University (UIN) Jakarta, Indonesia.

Aziz, Roikhan Mochamad. October 2008. The Assimilation of Sinlammim Into System Thinking In The Quantitative Method With Modeling On Sukuk As Islamic Economic Instrument. Proceeding.University of Malahayati, Lampung, Indonesia.

Fuad Nashori. Diani RR. 2002. Agenda Psikologi Islam. Kudus.

Kusminto \& Joko Budi Poernomo. Analisis Penilaian Kinerja dengan Teknik Self Assessment Sebagai Evaluasi Kinerja Mahasiswa pada Praktikum Fisika Dasar Ii Tadris Fisika Iain Walisongo. Semarang 